\title{
Expression and purification of the matrix protein of Nipah virus in baculovirus insect cell system
}

\begin{abstract}
Nipah virus (NiV) causes fatal respiratory illness and encephalitis in humans and animals. The matrix (M) protein of NiV plays an important role in the viral assembly and budding process. Thus, an access to the $\mathrm{NiV} \mathrm{M}$ protein is vital to the design of viral antigens as diagnostic reagents. In this study, recombinant DNA technology was successfully adopted in the cloning and expression of $\mathrm{NiV} \mathrm{M}$ protein. A recombinant expression cassette (baculovirus expression vector) was used to encode an $\mathrm{N}$-terminally His-tagged $\mathrm{NiV} \mathrm{M}$ protein in insect cells. A time-course study demonstrated that the highest yield of recombinant $M$ protein $(400-500 \mu \mathrm{g})$ was expressed from $10^{7}$ infected cells 3 days after infection. A single-step purification method based on metal ion affinity chromatography was established to purify the NiV M protein, which successfully yielded a purity level of $95.67 \%$ and a purification factor of 3.39. The Western blotting and enzyme-linked immunosorbent assay (ELISA) showed that the purified recombinant $\mathrm{M}$ protein $(48 \mathrm{kDa})$ was antigenic and reacted strongly with the serum of a NiV infected pig.
\end{abstract}

Keyword: Nipah virus; Matrix protein; Baculovirus; Insect cells; Expression; Purification 